\title{
The influence of soil nature on polyphenols in walnut tissues. A possible explanation of differences in the expression of walnut blight
}

\author{
Pascal Radix ${ }^{\mathrm{a}, \mathrm{c}}$, Catherine Bastien ${ }^{\mathrm{b}}$, Christian Jay-Allemand ${ }^{\mathrm{b}}$, \\ Gérard Charlot ${ }^{\mathrm{c}}$, Françoise Seigle-Murandi ${ }^{{ }^{*}}$
}

\begin{abstract}
${ }^{a}$ Laboratoire de botanique, cryptogamie, biologie cellulaire et génétique, groupe pour l'étude du devenir des xénobiotiques dans l'environnement (GEDEXE), UFR de pharmacie, université J.-Fourier (Grenoble I), BP 138, 38243 Meylan cedex, France

${ }^{\mathrm{b}}$ Station d'amélioration des arbres forestiers, Inra, centre de recherche d'Orléans, 45160 Olivet, France
\end{abstract}

c CTIFL, «Les Colombières », 38160 Chatte, France

(Received 11 August 1997; accepted 20 October 1998)

\begin{abstract}
Walnut blight is the major disease in the walnut orchards of Dauphine (France). The causal bacterium Xanthomonas campestris pv. juglandis can infect leaves, catkins, buds and nuts and can induce important crop losses. Field observations have shown that the nature of the soil seems to play a prominent role in crop losses. The hypothesis that soil may modify the amount of polyphenols in walnut tissues and modify the natural resistance of fruits to necrosis has been assumed. We have shown that the nature of the soil, especially its permeability, induces variations in polyphenols in walnut tissues. Differences of susceptibility to walnut blight between the two cultivars studied, Franquette and Parisienne, may also be explained by different behaviours in relation to polyphenols. Moreover, the massive use of copper treatments against walnut blight may induce an imbalance in polyphenol contents and could explain crop losses despite repeated copper sprays. (C) Inra/Elsevier, Paris.)
\end{abstract}

\section{Juglans / walnut blight / polyphenols / soil}

Résumé - Influence de la nature du sol sur la composition en polyphenols des tissus de noix. Une explication possible des différences observées dans l'expression de la bactériose du noyer. La bactériose est la principale maladie des noyers dans les vergers du Dauphiné (France). La bactérie responsable de cette maladie, Xanthomonas campestris pv. juglandis, infecte les feuilles, les chatons, les bourgeons, les fruits et peut causer d'importantes pertes de récolte. Des observations de terrain ont montré que la nature du sol semblait influencer l'importance des pertes de récolte. L'hypothèse que la nature du sol puisse modifier la composition en polyphénols des tissus et ainsi modifier la résistance naturelle des fruits à la nécrose a été faite. Nous avons montré que la nature du sol, spécialement sa perméabilité, induit des

Communicated by Gérard Guyot (Avignon)

*Correspondence and reprints

Tel: (33) (0)4 760410 04; fax: (33) (0)4 760410 05; e-mail: francoise.seigle.murandi@ujf-grenoble.fr 
variations dans la teneur en polyphénols des tissus. De même, les différences de sensibilité entre Franquette et Parisienne, les deux variétés étudiées, pourraient être expliquées par des différences de teneur en polyphénols. De plus, l'emploi massif de traitements cuivriques peut provoquer un déséquilibre dans la composition polyphénolique des tissus et pourrait expliquer dans certains cas, le manque d'efficacité de ces traitements. (@) Inra/Elsevier, Paris.)

\section{Juglans / bactériose du noyer / polyphénols / sol}

\section{INTRODUCTION}

Walnut (Juglans sp.) is an economically important tree crop in many countries around the world, such as Australia, Chile, China, France, India, Iran, Italy, Spain, USA, etc. Its production has been increasing steadily over the past decade, especially in the United States and in China [25]. Sixty percent of world exportations were by the USA, only $25 \%$ by China and $7 \%$ by both India and France [22]. Walnut blight is the major disease in the orchards of Dauphiné (SE France); it was already mentioned by Garavel in 1959 [8]. The causal bacterium Xanthomonas campestris pv. juglandis can infect leaves, catkins, buds and nuts [19]. Crop losses, due to necrosis of the fruit, can reach $60-80 \%$. Necrosis of the fruit constitutes the only real problem of this disease. At the beginning of the maturation of the fruit, harmful necrosis usually appears around the stigma as an oily dark brown spot. These young infected nuts generally fail to grow and, then, fall a few days later. Late season necrosis can stain the shell and make a part of the harvest unsellable. Up to now, the only way to reduce the damages caused by this disease has been to use periodical copper treatments although they are not always effective. Concern for environmental side-effects has restricted the use of copper-based treatments. Moreover, strains resistant to copper have been found $[4,9]$ and copper accumulation in the soil may disturb the metabolism of the trees [24].

Numerous field observations have shown that beyond the infection of walnut orchards by Xanthomonas campestris pv. juglandis, the nature of the soil and other factors such as the cultivar seem to play a prominent role in crop losses [6]. Very often, in spite of repeated copper treatments (eight sprays per year at $2.5 \mathrm{~kg} \mathrm{ha}^{-1} \mathrm{Cu}^{2+}$ each), it has been observed that orchards (especially for the Franquette cultivar) located on shallow, permeable and acidic soils are more damaged than orchards located on deep, poorly permeable and basic soils.

The wounding responses in plant tissues are often related to phenolic metabolism, and these responses have a general role in protecting the injured organ from infection $[1,16,20]$. The hypothesis that soil may modify the phenolic content of tissues and increase or decrease the natural resistance of fruit to blight has been submitted.

Naphtoquinones such as juglone (5-hydroxy-1,4 naphtoquinone) are major compounds of walnut tissues (especially of husk tissues) $[2,3,17]$. Hedin et al. [12, 13] established that juglone and related compounds accounted for the resistance of pecan (Carya illinoensis) to Fusicladium effusum; cultivars less affected by Fusicladium effusum generally had a higher level of juglone [12,13].

Moreover, these compounds are known for their toxicity to micro-organisms. Juglone is a depressant agent which immobilises and tranquillises fish, Daphnia, frogs and mammals [26]. Juglone inhibited Lemna minor growth, chlorophyll content and photosynthesis at treatments between 10 and $40 \mathrm{mM}$ [14]. The hypothesis that phenolic compounds could be used as stress detectors and could induce a change in the susceptibility of the fruit to this disease has been submitted. The first aim of this study was to reveal any possible influence of soil factors on the amount of phenolic compounds in husk tissues. In the second place, it was to show through biochemical disturbances that shallow, permeable, acidic soils, induce higher occurrences of necrosis.

The study was conducted in two parts. A first study aimed to find out which soil factors may influence the amount of phenolic compounds in 
husk tissues. A screening study, made to select the most pertinent factors, employed a fractional factorial design.

A second study, adapted from the results of the first experimental design, was conducted for a more acute analysis aiming to describe and explain soil effects on necrosis through variations in polyphenolic compounds. A complete factorial design was used.

\section{MATERIALS AND METHODS}

\subsection{Experimental design 1 (fractional factorial design $\mathbf{2}^{\mathbf{8}-\mathbf{4}}$ )}

In this exploratory experiment, 8 different factors of variation have been studied for their potential effect on the quantitative variations of some phenolic compounds. The effect of the nature of the soil was evaluated through three factors with two levels each (according to our experimental design requirements), corresponding to two physical characteristics, the depth of the soil (Dp) and its permeability $(\mathrm{Pm})$ and to one chemical characteristic, the $\mathrm{pH}(\mathrm{pH})$.
A possible cultivar effect $(\mathrm{CV})$ was taken into account by using two different varieties: Franquette which is the most common cultivar found in Dauphiné (with a medium susceptibility to walnut blight) and Parisienne, a cultivar that has been grown in Dauphiné for a longer time and is rather resistant to walnut blight.

In order to determine the possible role of copper treatment on walnut metabolism $(\mathrm{Cu})$, the absence or the presence of such a treatment was considered as the fifth factor. Copper sprays are usually performed from blossom to late growing, especially during rainy periods. No treatment is applied during fall and winter.

Nuts were collected from two different trees (Tree) in each selected orchard. Since preliminary analysis had proved that variability between fruits is negligible compared to variability between zones of tissue sampled on one fruit, only two factors of variation were studied at the fruit level. The first one was related to the presence or the absence of necrosis (Nec). The second one distinguished two parts in the tissues sampled on the nut, the apical zone and the parietal zone (Ti).

In order to combine a reduced size of the experiment with the analysis of numerous factors of variation, a fractional factorial design $2^{8-4}$ was finally chosen $[5,10]$. By this means, the study was limited to 32 tissue samples collected from only 16 different orchards (table I). Finally, data analysis tried to show any influences (statistically significant) of independent variables (factors)

Table I. Characteristics of the orchards studied, in relation to the fractional factorial design $2^{8-4}$.

\begin{tabular}{lccccc}
\hline Orchards & Depth & $\begin{array}{c}\text { Soil } \\
\text { permeability }\end{array}$ & pH & Cultivar & Copper treatment \\
\hline A & deep & poor & basic & Franquette & absence \\
B & deep & poor & basic & Franquette & presence \\
C & deep & poor & basic & Parisienne & absence \\
D & deep & poor & basic & Parisienne & presence \\
E & deep & permeable & acidic & Franquette & absence \\
F & deep & permeable & acidic & Franquette & presence \\
G & deep & permeable & acidic & Parisienne & absence \\
H & deep & permeable & acidic & Parisienne & presence \\
I & shallow & poor & acidic & Franquette & absence \\
J & shallow & poor & acidic & Franquette & presence \\
K & shallow & poor & acidic & Parisienne & absence \\
L & shallow & poor & acidic & Parisienne & presence \\
M & shallow & permeable & basic & Franquette & absence \\
$\mathrm{N}$ & shallow & permeable & basic & Franquette & presence \\
O & shallow & permeable & basic & Parisienne & absence \\
P & shallow & permeable & basic & Parisienne & presence \\
\hline
\end{tabular}


on dependent variables, i.e. the concentration of polyphenols in walnut husk tissues.

Independent variables (factors) were:

- Cv, Juglans regia cultivars: Franquette (Fr) or Parisienne $(\mathrm{Pa})$;

- Cu, copper treatment: absence or presence;

- Dp, soil depth: deep or shallow;

- Pm, soil permeability: permeable or poorly permeable;

- $\mathrm{pH}$, soil $\mathrm{pH}$ : acidic or basic;

- Nec, necrosis: absence or presence;

- Ti, tissue: apex (1) or parietal (2);

- Tree, tree: tree $n_{i} 1$ or tree $n_{i} 2$;

Dependent variables were:

- JUG, juglone concentration;

- HJG, hydrojugloneglucoside concentration;

- MYR, myricitrin concentration;

- QUE, quercitrin concentration;

- CAF, caffeic acid concentration;

- HCA, hydroxycinnamic acid concentration (partially identified);

- FLV , flavonol 1 concentration (partially identified);

- $\mathrm{FLV}_{2}$, flavonol 2 concentration (partially identified);

- $\mathrm{FLV}_{3}$, flavonol 3 concentration (partially identified); Sample collection:

Samples were collected in each orchard from two different trees, at four different times (June 2, June 17, June 26 , July 7 1993) corresponding to four different phenological stages. Orchards differed in at least one of these three factors: soils, Juglans regia cultivars (Franquette or Parisienne) and copper treatment (absence or presence).

Only nuts were collected (10 nuts per sample) and immediately immersed in situ in liquid nitrogen (only a few seconds elapsed between picking and freezing). Then, samples were freeze-dried and stored under vacuum in darkness.

\subsection{Experimental design 2 (complete factorial design $2^{4}$ )}

After the results of the first experimental design, we selected the most relevant factors in order to constitute a complete factorial design $2^{4}$. Only sound nuts were selected and analysed in this part.

Independent variables (factors) were:

- Cv, Juglans regia cultivars: Franquette (Fr) or Parisienne $(\mathrm{Pa})$;

- $\mathrm{Cu}$, copper treatment: absence or presence;
- Pm, soil permeability: permeable (1) or poorly permeable (2);

- Ti, tissue: apex (1) or parietal (2).

Dependent variables were:

- JUG, juglone concentration;

- HJG, hydrojugloneglucoside concentration;

- MYR, myricitrin concentration;

- QUE, quercitrin concentration;

- CAF, caffeic acid concentration;

- HCA, hydroxycinnamic acid concentration (partially identified);

- NAPH, naphtoquinone concentration (partially identified);

- FLAV, flavane concentration (partially identified).

Minor partially identified flavonol 1,2,3 were ruled out in this experimental design according to the results obtained in the first analysis. On the other hand, two other compounds (belonging to naphtoquinone and flavane families) were included because high concentrations were found during the exploratory experiment. They were implicated in interactions between cultivar, copper treatment and permeability as well.

\subsection{Analysis of soluble phenolic compounds}

Phenolic compounds were extracted from husk tissues and quantified according to a method described by JayAllemand [15]. About $20 \mathrm{mg}$ of dry tissue was cut off from the freeze-dried fruit, and put in a 2-mL Eppendorf tube. Then $2 \mathrm{~mL}$ of acetone/water $(4 / 1, \mathrm{v} / \mathrm{v})$ mixture with $25 \mathrm{mg} \mathrm{L}^{-1}$ of 6-methoxyflavone as standard, were poured in the Eppendorf tube and was homogenised by ultrasound for $30 \mathrm{~min}$. Centrifugation at $12000 \mathrm{rd} \mathrm{min}-1$ $(11250 \mathrm{~g}$ ) lasted $20 \mathrm{~min}$. Then $500 \mu \mathrm{L}$ of supernatant were removed and dried under vacuum by means of the Speed-Vac system. Finally, the dry residue was diluted with $1 \mathrm{~mL}$ methanol to constitute the final sample for HPLC quantification. Samples were kept at $4{ }^{\circ} \mathrm{C}$ throughout the extraction phase.

Analyses were performed by HPLC Multisolvent Delivery System Waters (600E) with Photodiode Array Detector (Waters 991), Sample Processor (Waters Ultrawist 715), Powermate SX Plus Computer NEC. Conditions for phenolic analysis were: Column SFCC Hypersil C18 $(5 \mu \mathrm{m}, 25 \mathrm{~cm})$; a linear gradient elution using solvent $\mathrm{A}$ acetonitrile/methanol $(50 / 50, \mathrm{v} / \mathrm{v})$, solvent B water ( $1 \%$ acetic acid) was programmed from $15 \%$ to $40 \%$ A for $20 \mathrm{~min}$, then from $40 \%$ to $60 \% \mathrm{~A}$ for $5 \mathrm{~min}$. then from $60 \%$ to $100 \% \mathrm{~A}$ for $5 \mathrm{~min}$, then $100 \% \mathrm{~A}$ for $10 \mathrm{~min}$, then from $100 \%$ to $15 \% \mathrm{~A}$ for 5 min, with a flow rate of $1 \mathrm{~mL} \mathrm{~min}{ }^{-1}$ Detection was performed at $340 \mathrm{~nm}$ and scanning from 220 to $450 \mathrm{~nm}$. 
Compounds were identified by their retention time and their spectrum in comparison with standards. Peak area was calculated in relation to an internal standard (6methoxyflavone). Juglone, hydrojugloneglucoside, myricitrin and quercitrin were quantified as absolute values. Values were expressed in $\mathrm{mg}$ of compound/g dry weight (DW) of husk tissues.

\subsection{Data analysis}

Data were analysed according to the factorial design requirements with the S System software.

The effects of the different factors of variation on the amount of each phenolic compound were tested through an analysis of variance (ANOVA). Multivariate analysis for each date of collection were conducted through the principal component analysis (PCA).

\section{RESULTS}

The preliminary results (not presented) obtained from the first experimental design have mainly

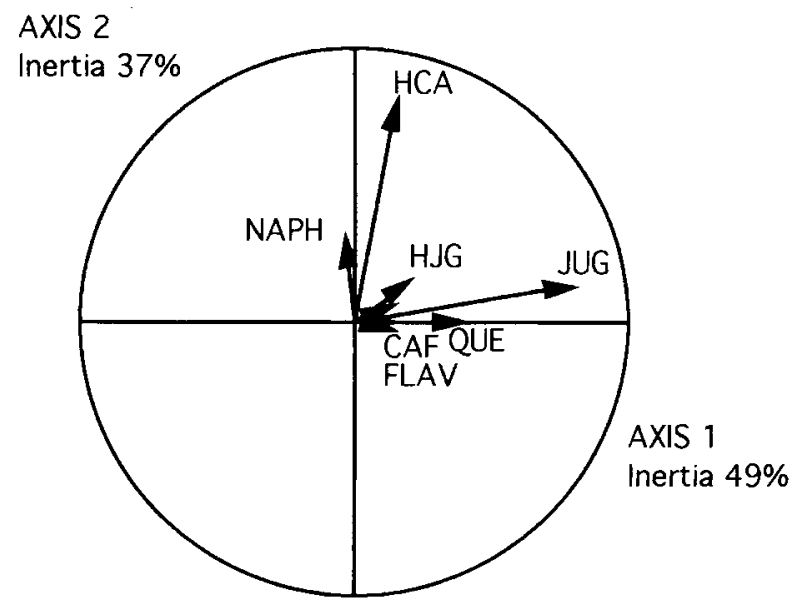

TIME 1

JUG concentration of juglone

HJG concentration of hydrojugloneglucoside QUE concentration of quercitrin

HCA concentration of hydroxycinnamic acid

CAF concentration of caffeic acid

FLAV concentration of flavane

$\mathrm{NAPH}$ concentration of naphtoquinone shown that phenolic variations were especially due to the state of maturation of the fruit, the cultivar, the tissue and soil permeability. The highest variations of polyphenols content in husk tissues were observed during the early stages of development of fruits when the most necroses generally occur. For these reasons, only the early stages of development (sampling times 1 and 2) were further studied.

\subsection{Correlations between polyphenol contents in walnut husk tissues}

The principal component analysis showed that most of the variations (86 and $94 \%$ according to the sampling times 1 and 2 , respectively) among phenolic compounds were explained by the first two principal components (figure I). Moreover, these two principal components were mainly represented by juglone (principal component 1) and hydoxycinnamic acid (principal component 2). This

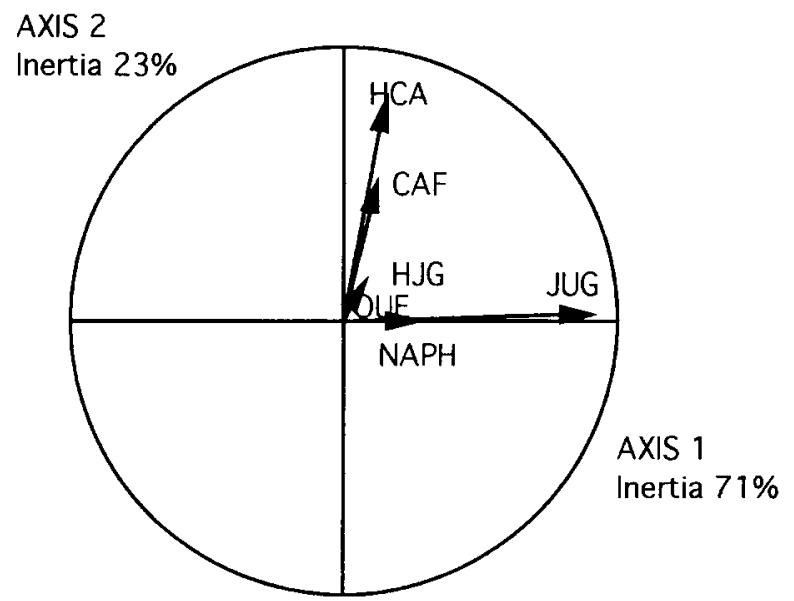

TIME 2

Figure 1. Correlation between polyphenol contents in walnut husk tissues. Principal component analysis was performed with the second experimental design (complete factorial design) data. Correlation circles for the two sampling times (June 2, June 17) are shown. 
means that all the variations between the 7 phenolic compounds studied are well described by only the juglone and the hydoxycinnamic acid components. In particular, at sampling time 2 (June 17), the first two principal components (axes 1,2) explained almost all the variations (94\%), and juglone alone explained almost $71 \%$ of the variations. This suggests that regulations between polyphenolic compounds exist as has been previously demonstrated $[11,18]$.

\subsection{Influence of the factors of variations (soil permeability, copper treatment, cultivar, tissue) on polyphenols contents in walnut husk tissues}

Analysis of variance was performed in order to find out which factors were the most significant for the explanation of the variations of polyphenol content among walnut husk tissues (table $I I$ ). Concentrations of juglone, hydrojugloneglucoside,

Table II. Influence of the 8 factors of variation on polyphenol contents in walnut husk tissues at the first two sampling times. ANOVA was performed with 8 variables (polyphenol contents) and 4 factors of variation (cultivar, soil permeability, copper treatment, tissue). Values indicate $P$-values of the principal effects and interactions. Only significant effects at a $10 \%$ level $(\operatorname{Pr}(\mathrm{F})<10 \%)$ are considered.

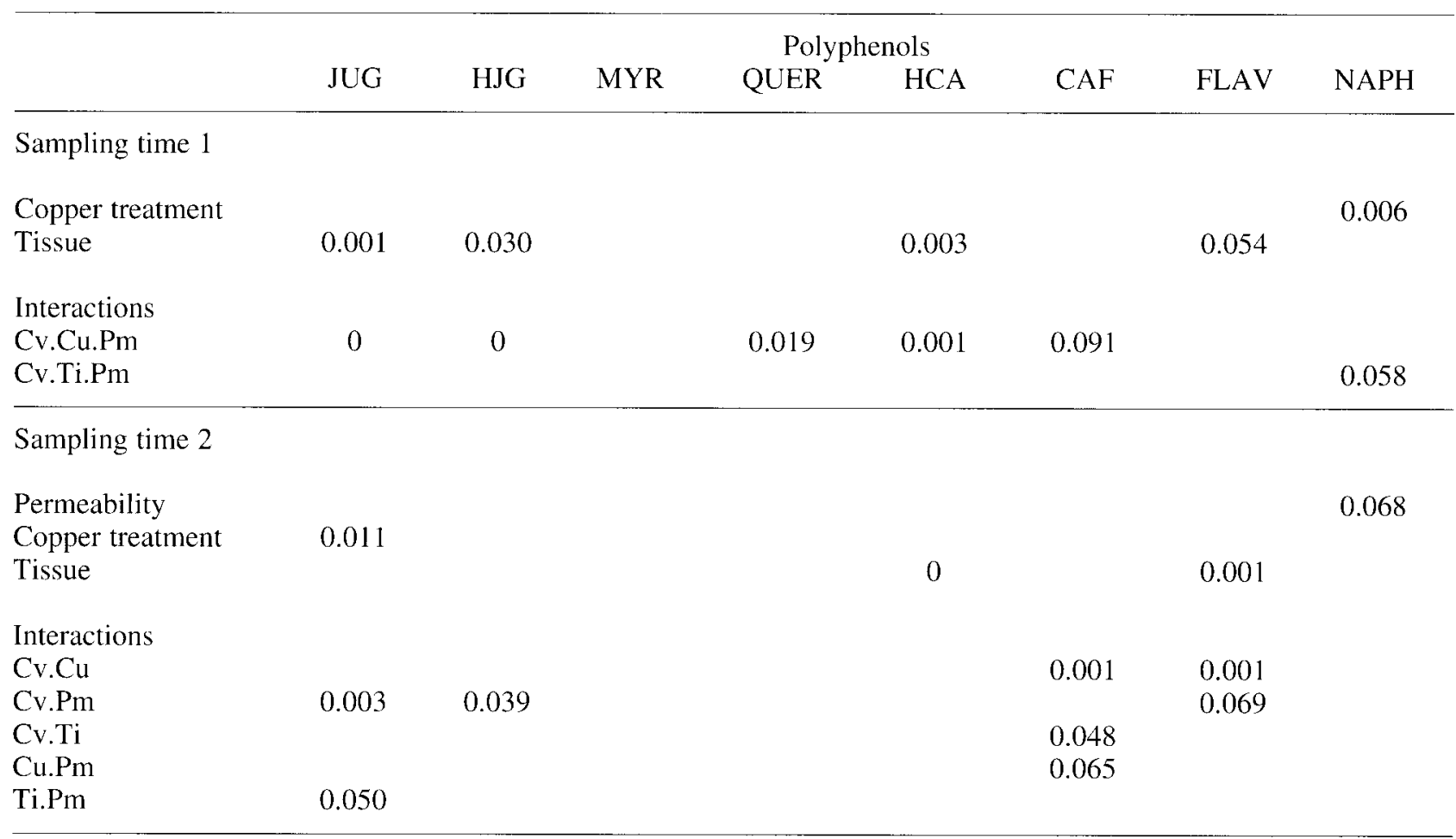

Cv.Cu $=$ interaction Cultivar $\times$ Copper treatment

Cv.Pm $=$ interaction Cultivar $\times$ Soil permeability

Cv.Ti $=$ interaction Cultivar $\times$ Tissue

Cu.Pm = interaction Copper treatment $\times$ Soil permeability

Ti.Pm $=$ interaction Tissue $\times$ Soil permeability

Cv.Cu.Pm $=$ interaction Cultivar $\times$ Copper treatment $\times$ Soil permeability

Cv.Ti.Pm $=$ interaction Cultivar $\times$ Tissue $\times$ Soil permeability 
hydroxycinnamic acid and flavane were significantly different between apical and parietal tissues during the early stage of development of the fruit (sampling time 1). Naphtoquinone concentration was modified by copper treatment as well. Two weeks later (sampling time 2), hydroxycinnamic acid and flavane concentrations were significantly different between apical and parietal tissues and juglone concentration was modified by copper treatment.

\subsection{Interactions between factors}

The interactions between factors play an essential role in the global understanding of the problem. A description of the effects of these interactions between factors of variation on polyphenol contents is presented in figure 2. The cultivar factor is involved in most of the interactions. This indicates that Franquette and Parisienne cultivars have different responses in polyphenols contents either in presence of copper treatment or with regard to the permeability of the soil.

\subsection{Influence of copper treatment, soil permeability and tissue factors on polyphenol contents in walnut husk tissues}

Table III indicates adjusted means for each significant factor. These means were calculated with consideration for the interactions. We notice that hydrojugloneglucoside constitutes more than $20 \%$ of the husk tissues dry weight. For both sampling times, apical husk tissues have higher levels of juglone, hydrojugloneglucoside, hydroxycinnamic acid and flavane than parietal tissues. Copper treatment globally induced a reduction in juglone content.

\section{DISCUSSION}

Results shown in table II indicate that the 'tissue' factor is the main effect in the explanation of the variations of polyphenols. Numerous field observations have revealed that necrosis appeared almost always at the apex of the fruit. The significant difference in composition of the two tissues (apical, parietal) may be an explanation for this observation.

Table III shows that at sampling time 2 (when blight damages are most important), the concentration of juglone decreased in the presence of copper in the soils and we have already established a relationship between high levels of copper in soils and the importance of crop losses [21]. It was established by Hedin et al. [13] that juglone could account for the resistance of the fruit to blight damages: the higher the level of juglone, the higher the resistance. Even if copper did not appear as a prominent factor, it played a significant role in some interactions with other factors such as necrosis, cultivar and soil depth (figure 2). It was established in previous studies $[7,24]$ that copper accumulation in the soil may disturb the metabolism of trees, and we found in some orchards a copper content more than fifteen times the average. These results seem to indicate that copper treatments not only have a poor efficiency but induce metabolic disturbance in some cases.

\subsection{Effects of interactions between factors on polyphenol contents in husk tissues}

Field observations have revealed that orchards set on permeable and rather acidic soils and the Franquette cultivar are always more damaged than other orchards, in spite of copper treatment. An increased synthesis of cinnamic acid derivatives, such as caffeic acid, flavonoids, etc., and their accumulation in plant tissues are stimulated by wounding or stress [23]. This may be explained by some interactions among the factors described in this study (figure 2).

The juglone content in walnut husk tissues was influenced by both the cultivar and the soil's permeability (figure $2 a$ ). We have found an important difference of behaviour between the two types of soil, mainly for $\mathrm{cv}$. Franquette $\left(10 \mathrm{mg} \mathrm{g}^{-1}\right.$ juglone in 

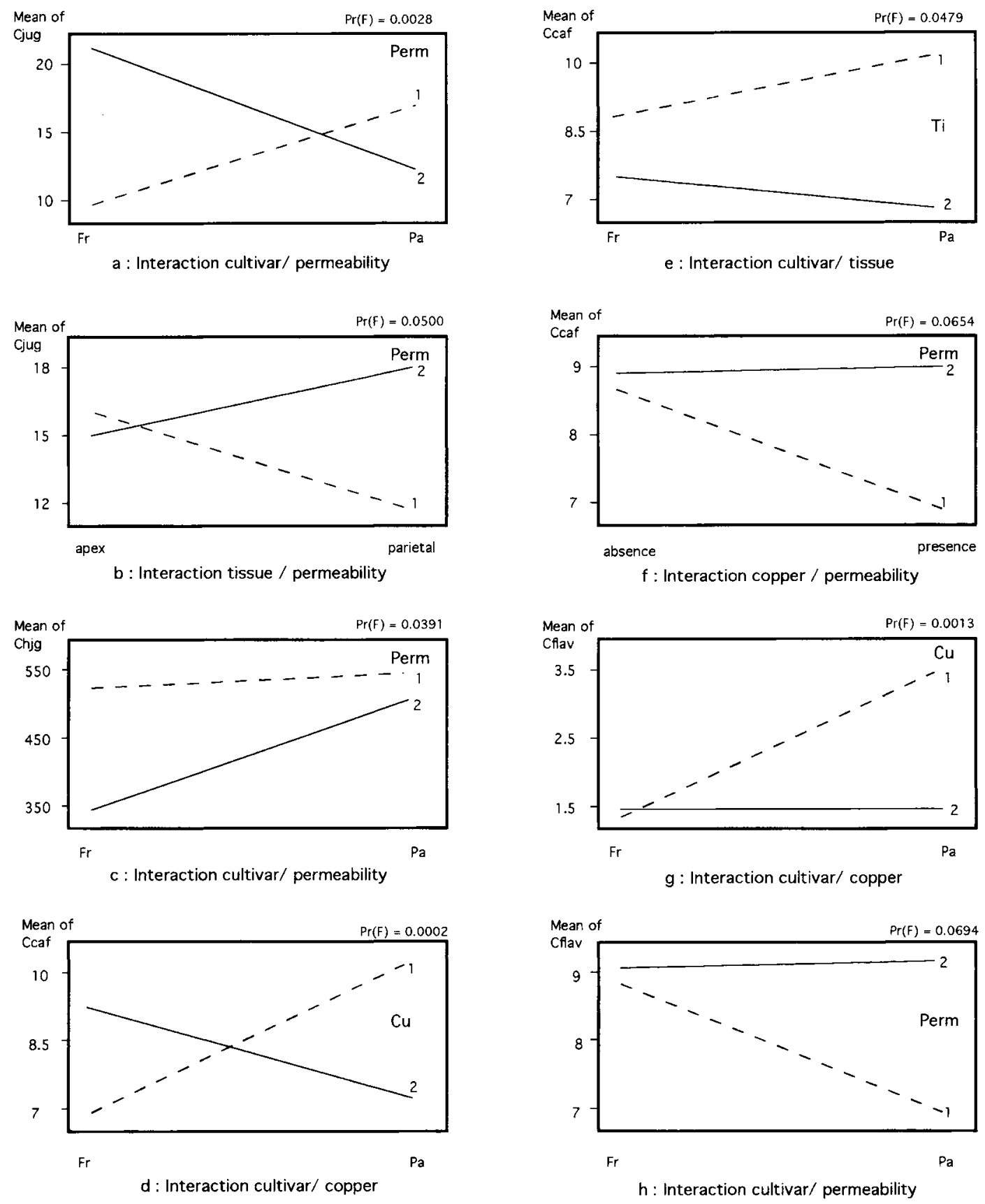

Perm 1 : poorly permeable

Perm 2 : permeable

Cu 1 : presence of copper

Chig : concentration of hydrojugloneglucoside

Ccaf : concentration of caffeic acid

$\mathrm{Cu} 2$ : absence of copper

$\mathrm{Fr}: \mathrm{cv}$. Franquette

$\mathrm{Pa}: \mathrm{cv}$. Parisienne

Ti 1 : apex

Ti 2 : parietal

$\operatorname{Pr}(\mathrm{F})$ : risk $\alpha$

Figure 2. Influence of cultivar, soil permeability, tissue and copper treatment on polyphenol contents in walnut husk tissues. Description of the significant interactions $(\operatorname{Pr}(\mathrm{F})<10 \%)$ between factors of variation. 
Table III. Influence of copper treatment, soil permeability and tissue on polyphenol contents in walnut husk tissues. Values are adjusted means of polyphenol contents and are expressed in $\mathrm{mg} \mathrm{g}^{-1}$ dry weight. Only significant effects at a $10 \%$ level $(\operatorname{Pr}(\mathrm{F})<10 \%)$ are presented.

\begin{tabular}{|c|c|c|c|c|c|c|}
\hline & & JUG & HJG & $\begin{array}{l}\text { Polyphenols } \\
\text { HCA }\end{array}$ & FLAV & NAPH \\
\hline $\begin{array}{l}\text { Sampling time } 1 \\
\text { Copper treatment }\end{array}$ & $\begin{array}{l}\text { absence } \\
\text { presence }\end{array}$ & & & & & $\begin{array}{l}5.47 \pm 0.2 \\
2.48 \pm 0.2\end{array}$ \\
\hline Tissue & $\begin{array}{c}\text { apex } \\
\text { parietal }\end{array}$ & $\begin{array}{l}19.0 \pm 0.4 \\
15.2 \pm 0.4\end{array}$ & $\begin{array}{l}282 \pm 5.2 \\
216 \pm 5.2\end{array}$ & $\begin{array}{l}18.6 \pm 0.3 \\
15.5 \pm 0.3\end{array}$ & $\begin{array}{l}1.6 \pm 0.2 \\
0.8 \pm 0.2\end{array}$ & \\
\hline $\begin{array}{l}\text { Sampling time } 2 \\
\text { Permeability }\end{array}$ & $\begin{array}{c}\text { permeable } \\
\text { poorly permeable }\end{array}$ & & & & & $\begin{array}{l}4.3 \pm 0.3 \\
5.3 \pm 0.3\end{array}$ \\
\hline Copper treatment & $\begin{array}{l}\text { absence } \\
\text { presence }\end{array}$ & $\begin{array}{l}18.0 \pm 1.1 \\
12.1 \pm 1.1\end{array}$ & & & & \\
\hline Tissue & $\begin{array}{c}\text { apex } \\
\text { parietal }\end{array}$ & & & $\begin{array}{l}15.9 \pm 0.5 \\
10.1 \pm 0.5\end{array}$ & $\begin{array}{l}2.9 \pm 0.17 \\
1.6 \pm 0.17\end{array}$ & \\
\hline
\end{tabular}

poorly permeable soils / $22 \mathrm{mg} \mathrm{g}^{-1}$ in permeable soils). The higher susceptibility of Franquette to necrosis may be explained by the fact that the permeability of the soil strongly affects the level of juglone in Franquette husk tissues whereas it does not in Parisienne. Moreover, soil permeability influences juglone contents in parietal tissues but very little in apical tissues (figure $2 b$ ).

The hydrojugloneglucoside content in walnut husk tissues was also influenced by both the cultivar and the soil's permeability (figure $2 c$ ). Concentrations of hydrojugloneglucoside in Parisienne fruit (500 $\mathrm{mg} \mathrm{g}^{-1} \mathrm{DW}$ ) were higher than in Franquette fruits $\left(350 \mathrm{mg} \mathrm{g}^{-1} \mathrm{DW}\right.$ ) for trees located in permeable soils. This could also explain why Franquette is more sensitive to necrosis than Parisienne, especially in permeable soils.

The presence or the absence of copper treatment induced a reverse behaviour in the two cultivars as far as the amount of caffeic acid in the husk tissues of their fruit was concerned (figure $2 d$ ). In permeable soils, Franquette $\left(9 \mathrm{mg} \mathrm{g}^{-1} \mathrm{DW}\right)$ has a higher content of caffeic acid than Parisienne $\left(7.2 \mathrm{mg} \mathrm{g}^{-1}\right.$
DW); in poorly permeable soils, the reverse situation is found.

Differences in caffeic acid contents between apical tissues $\left(10 \mathrm{mg} \mathrm{g}^{-1} \mathrm{DW}\right)$ and parietal tissues (6.9 $\left.\mathrm{mg} \mathrm{g}^{-1} \mathrm{DW}\right)$ are higher for the Parisienne cultivar (figure $2 e$ ).

On the other hand, the presence of copper treatment influences caffeic acid contents between permeable ( $9 \mathrm{mg} \mathrm{g}^{-1} \mathrm{DW}$ ) and poorly permeable ( $7 \mathrm{mg} \mathrm{g}^{-1} \mathrm{DW}$ ) soils. Without any copper treatment, the caffeic acid content in husk tissues is roughly the same whatever the soil permeability (figure $2 f$ ). This increased level of caffeic acid may indicate a stress due to copper. In this way, flavane content is more influenced by presence of copper treatment in the Parisienne cultivar than in the Franquette cultivar (figure $2 \mathrm{~g}$ ). Likewise, flavane content was higher for the Franquette cultivar $\left(8.9 \mathrm{mg} \mathrm{g}^{-1} \mathrm{DW}\right)$ than for the Parisienne cultivar $\left(7 \mathrm{mg} \mathrm{g}^{-1} \mathrm{DW}\right)$ in poorly permeable soils, and roughly the same in permeable soils (figure $2 h$ ). 
All of these effects indicated that the nature of the soil certainly modified polyphenol content in walnut tissues. As polyphenols are involved in necrosis pathways as well as resistance, we can hypothesise that the nature of the soil influences the expression of walnut blight through biochemical mechanisms involving polyphenols.

\section{CONCLUSION}

Even if some questions are not clarified yet, this study has shown that the nature of the soil, especially its permeability, induces variations of polyphenol contents in walnut husk tissues. Likewise, differences observed in apical tissues may explain why it is the apex of the fruit which is chiefly damaged by necrosis. Differences in sensitiveness to walnut blight between the two cultivars studied, Franquette and Parisienne, may also be explained by different behaviours in relation to polyphenols. The use of copper for the control of walnut blight is more and more questioned, the accumulation of copper is alarming in many orchards, and this study has shown that copper in the soil induces disturbances in polyphenols.

\section{REFERENCES}

[1] Agrios G.N., Plant Pathology, Academic Press, San Diego, 1997.

[2] Binder R.G., Benson M.E., Flath R.A., Eight 1,4naphtoquinones from Juglans, Phytochemistry 28 (1989) 2799-2801.

[3] Borazjani A., Graves C.H., Hedin P.A., Occurrence of juglone in various tissues of pecan and related species, Phytopathology 75 (1985) 1419-1421.

[4] Brault T., Étude de la résistance au cuivre chez Xanthomonas campestris pv. juglandis sur noyer, DEA, Université de Rennes, Inra, Angers, 1990.

[5] Chapouille P., Planification et analyse des expériences, Masson, Paris, 1973.

[6] Charlot G., Penet C., Compte rendu des travaux de recherche et expérimentations entrepris à la station de
Chatte en 1988, Rapport CTIFL 1988, Station de Chatte (1988) 122-123.

[7] Delas J., La toxicité du cuivre accumulé dans les sols, Agrochimica 7 (1963) 258-287.

[8] Garavel L., La culture du noyer, Baillière et fils, Paris, 1959.

[9] Gardan L., Brault T., Germain E., Copper resistance of Xanthomonas campestris pv. juglandis in French walnut orchards and its association with conjugative plasmids, Acta Hortic. 311 (1993) 117-124.

[10] Goupy J., La méthode des plans d'expérience, Dunod, Paris, 1988.

[11] Harborne J.B., Plant phenolics, in: Bell E.A., Charlwood B.V. (Eds.), Encyclopedia of Plant Physiology, Secondary Plant Products, vol. 8, Springer Verlag, Berlin, 1980, pp. 329-402.

[12] Hedin P.A., Langhans V.E., Graves C.H., Identification of juglone in pecan as a possible factor of resistance to Fusicladium effusum, J. Agric. Food Chem. 27 (1979) 92-94.

[13] Hedin P.A., Collum D.H., Langhans V.E., Graves C.H., Distribution of juglone and related compounds in pecan and their effect on Fusicladium effusum, J. Agric. Food Chem. 28 (1980) 340-342.

[14] Heijl A.M., Einhellig F.A., Rasmusen J.A., Effect of juglone on growth, photosynthesis and respiration, J. Chem. Ecol. 19 (1993) 559-568.

[15] Jay-Allemand C., Les marqueurs biochimiques de la juvénilité chez le noyer (Juglans nigra et Juglans nigra $\times$ Juglans regia), Ph.D. thesis, Université des sciences et techniques du Languedoc, Montpellier, 1985.

[16] Lagrimini L.M., Vaughn J., Erb W.A., Miller S.A., Peroxidase overproduction in tomato: woundinduced polyphenol deposition and disease resistance, Hortscience 28 (1993) 218-221.

[17] Lee K.C., Campbell R.W., Nature and occurrence of juglone in Juglans nigra L., Hort. Sci. 4 (1969) 297-298.

[18] Leistner E., Biosynthesis of plant quinones, in: Stumpf P.K., Conn E.E. (Eds.), The Biochemistry of the Plants: A Comprehensive Treatise, Secondary Plant Products, vol. 7, Academic Press, New York, 1981, pp. 403-423.

[19] Mulrean E.N., Schroth M.N., Bacterial blight on Persian walnuts, California Agric. (1981) 11-13.

[20] Nicholson R.L., Hammerschmidt R., Phenolic compounds and their role in disease resistance, Annu. Rev. Phytopathol. 30 (1992) 369-389. 
[21] Radix P., Seigle-Murandi F., Hazards of copper accumulation in soils of walnut orchards, Fresenius Environ. Bull. 2 (1993) 565-569.

[22] Rastoin F., La noix, son avenir. Les tendances de la consommation européenne, Colloque : La noix, réussir sa qualité, Creysse, 17.09.1993, eds CTIF, Paris.

[23] Rhodes J.M., Wooltorton L.S.C., The biosynthesis of phenolic compounds in wounded plant storage tissues, in: Kahl G. (Ed.), Biochemistry of Wounded Plant
Tissues, Springer-Verlag, Berlin, New York, 1978, pp. $248-276$.

[24] Salgare S.A., Asthana S., Copper an environmental pollutant, Environ. Ser. 3 (1990) 101-119.

[25] Siebert J.B., Economic and policy considerations in marketing walnuts, Acta Hortic. 311 (1993) 249-257.

[26] Westfall B.A., Russell R.L., Auyong T.K., Depressant agent from walnut hulls, Science 134 (1961) 1517. 